\title{
Long-lasting hydrocephalus in hyh mutant mice: gain and loss of a brain surviving hydrocephalus Esteban M Rodríguez ${ }^{* 1}$, Patricia Páez ${ }^{2}$, Federico Bátiz ${ }^{1}$, Carolina Wagner ${ }^{1}$,

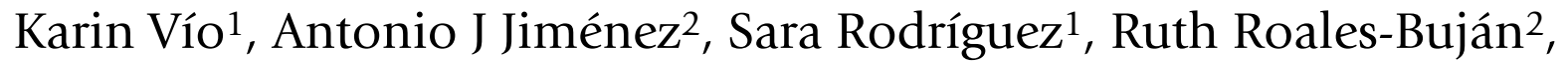 Luis M Rodrígez-Pérez ${ }^{2}$ and José-Manuel Pérez-Fígares²
}

\author{
Address: ${ }^{1}$ Instituto de Histología y Patología, Universidad Austral de Chile, Valdivia, Chile and ${ }^{2}$ Departamento de Biología Celular, Facultad de \\ Ciencias, Universidad de Málaga, Málaga, España, Instituto de Histología y Patología, Universidad Austral de Chile, Valdivia, Chile \\ Email: Esteban M Rodríguez* - erodrigu@uach.cl \\ * Corresponding author
}

from 50th Annual Meeting of the Society for Research into Hydrocephalus and Spina Bifida

Cambridge, UK. 30 August - 2 September 2006

Published: 21 December 2006

Cerebrospinal Fluid Research 2006, 3(SuppI I):SI5 doi:I0.1186/1743-8454-3-SI-SI5

(c) 2006 Rodríguez et al; licensee BioMed Central Ltd.

\section{Background}

A population $(30 \%)$ of hydrocephalic $h y$ mutant mice develop a slowly progressive hydrocephalus and survive for periods ranging between 2 months and 2 years. Certain characteristics of these mice, such as time of onset of hydrocephalus, type of abnormality of CSF dynamics, clinical evolution and survival/death rate, resemble several types of human congenital hydrocephalus. They represent an exceptional animal model to investigate neuropathological and physiopathological aspects of a brain "adapting" to a virtually life-lasting hydrocephalus

\section{Materials and methods}

(i) The clinical evolution of more than 3,000 hyh mice,(ii) certain cellular and molecular aspects involved in the pathogenesis of hydrocephalus of several hundreds of embryos and postnatal hyh specimens and, (iii) the neuropathology of more than one hundred hydrocephalic mice with arrested hydrocephalus have been investigated with a large series of techniques.

\section{Results}

The events occurring in the brain of aging hydrocephalic mice may be regarded as loss and gain. Loss: Neuroepithelium/ependyma denudation is a severe loss, since it leads to (i) Sylvius aqueduct obliteration and severe hydrocephalus; (ii) abnormal development of certain populations of cerebral neurons resulting in a permanent neurological impairment. Abnormalities in the subcommissural organ contribute to the development of hydrocephalus and to changes in the protein composition of CSF. Severe alterations of hypothalamus lead to neuroendocrine deficiencies. Gain: (i) A subpopulation of astrocytes responds to denudation by repairing the denuded areas forming an ependymal-like new barrier. (ii) Once severe hydrocephalus has been turned on, two ependymal populations located in the aqueduct and third ventricle start to proliferate allowing the large expansion of these cavities. This ependymogenesis continues for several weeks after birth. (iii) All mice surviving hydrocephalus developed spontaneous ventriculostomies.

\section{Conclusion}

(i) Essential events of the hydrocephalic phenomenon occur at a rather well defined temporal and spatial pattern in which a program of sequential events may be envisaged. (ii) None of the pathological events should be regarded as the result of mechanical phenomena. Rather, abnormalities occurring at molecular and cellular levels and leading to ependymal denudation and abnormal neurogenesis, precede the onset of hydrocephalus. (iii) Postnatal ependymogenesis and spontaneous ventriculostomies are essential for the hydrocephalic mice to live a long life. 


\section{Grants}

Fondecyt 1030265, Chile to EMR; FIS PI 030756, Red CIEN (C/0306), SAS, Spain to JMP-F.

Publish with Bio Med Central and every scientist can read your work free of charge

"BioMed Central will be the most significant development for disseminating the results of biomedical research in our lifetime. " Sir Paul Nurse, Cancer Research UK

Your research papers will be:

- available free of charge to the entire biomedical community

- peer reviewed and published immediately upon acceptance

- cited in PubMed and archived on PubMed Central

- yours - you keep the copyright 